\title{
Study of irisin hormone level in type 2 Diabetic patients and patients with diabetic
}

Nephropathy

Salah Shelbaya*,Manal Abushady*, Merhan Samy* and Yasmine Abd-AI Mageed *Magdy Abbas**

"Division of endocrinology, Department of internal Medicine, ${ }^{*}$ Fellow of chemistry Ain Shams University Hospital, Cairo, Egypt.

Objectives:

Irisin hormone is normally present as part of a larger protein Fibronectin domain-containing protein 5 (FNDC5) in a muscle cell's outer membrane, where it lies dormant and inactive. Exercise (and other unknown factors) cause this protein to be split, releasing irisin, which exits the muscle cell to other cells of the body causing conversion of some white fat cells to brown fat cells and islet cells of pancreas which are told to produce more insulin . ${ }^{1}$

There is controversy concerning irisin level in plasma that it is reduced in Type 2 Diabetic . ${ }^{2}$ Preliminary studies suggest that irisin is decreased in Type 2 diabetic patients with renal insufficiency $\left(\right.$ GFR $\left.<60 \mathrm{ml} / \mathrm{min} / 1.73 \mathrm{~m}^{2}\right){ }^{3}$ We aimed in this work is to study Irisin Hormone level in Type 2 diabetic patient . Also, to study the relation between Irisin Hormone level and diabetic nephropathy.

\section{Methods:}

We recruited 60 type 2 diabetic subjects and 30 healthy controls. Diabetics will be divided into 30 patients without complications and 30 with diabetic nephropathy(DN). Serum Irisin, fasting blood glucose(FBG), 2hours plasma glucose (2hPG), hemoglobin A1c, serum creatinine and albumin/ creatinine ratio were measured.

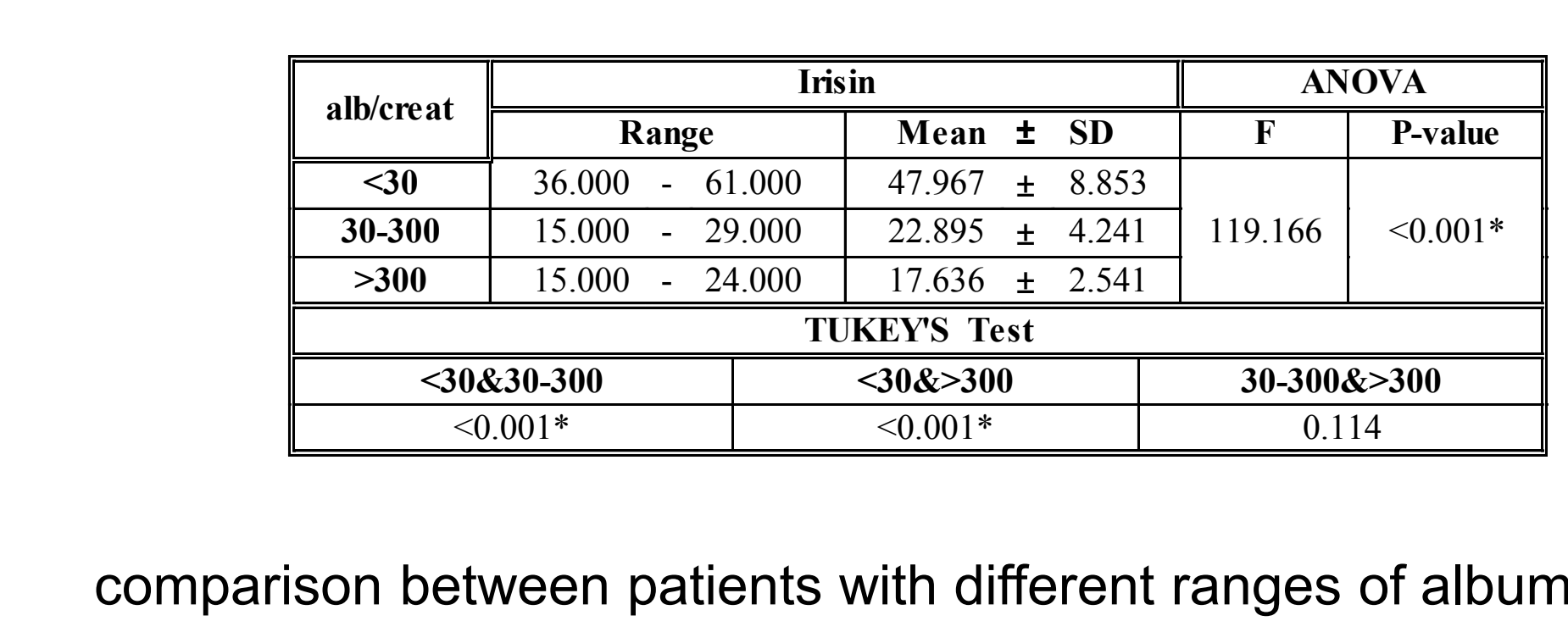
comparison between patients with different ranges of albuminuria as
regard serum Irisin

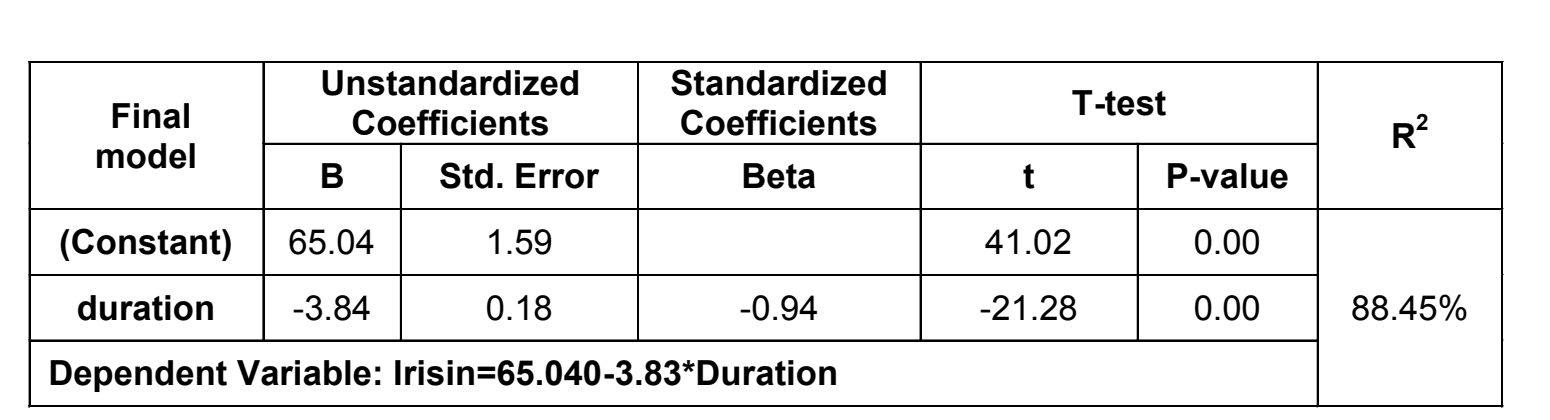

Stepwise Regression Analysis for determination of the most important predictor of serum irisin
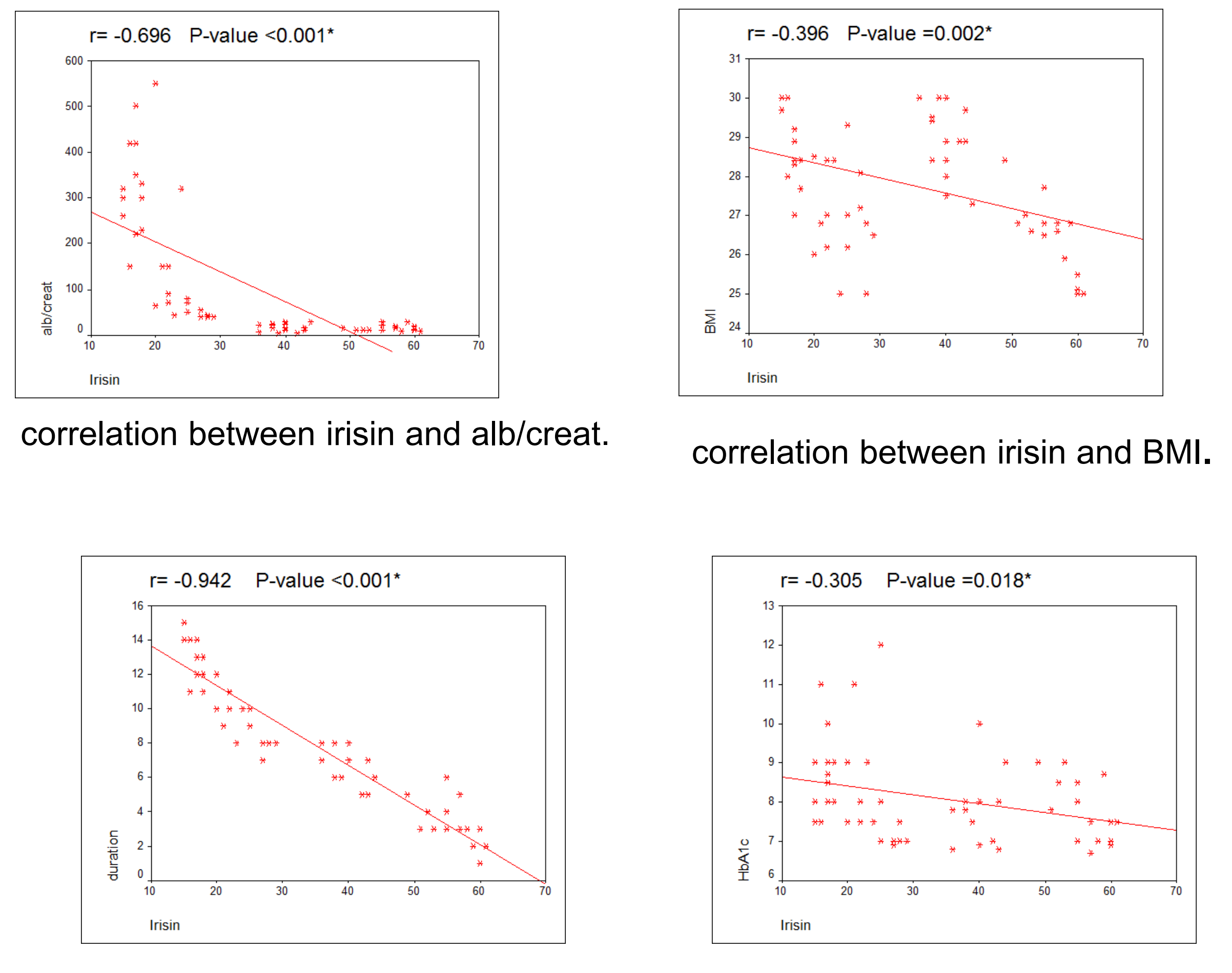

correlation between irisin and duration of diabetes.

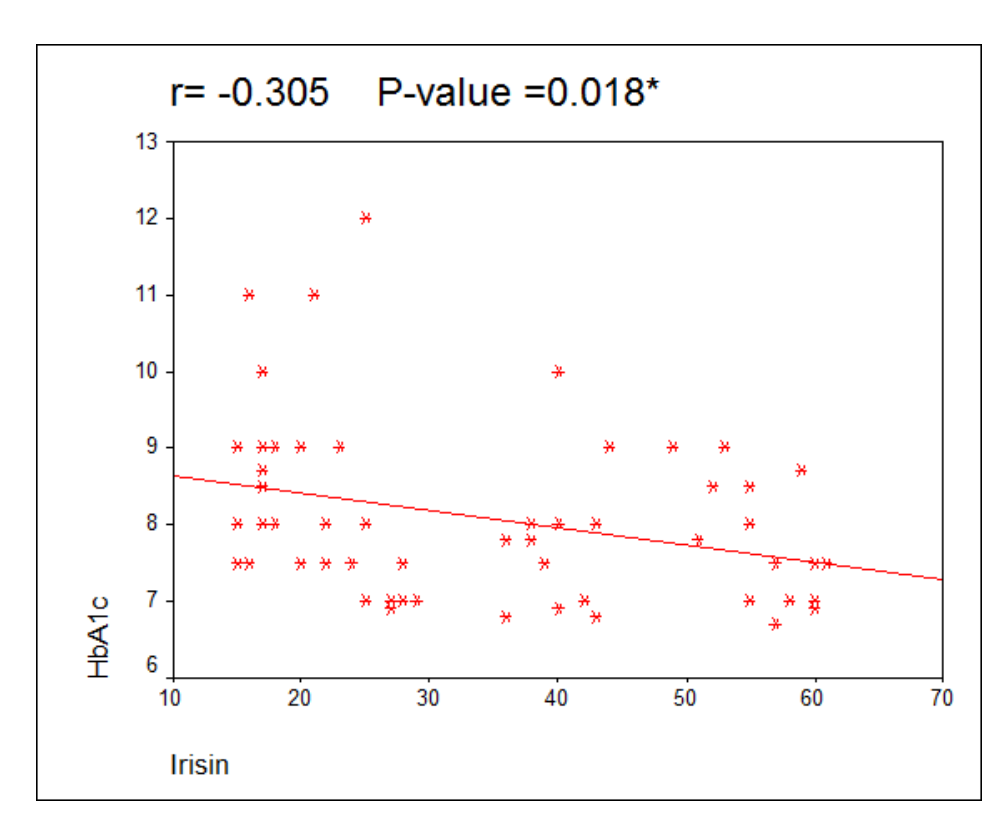

correlation between irisin and HbA1c.

\section{Results:}

\section{Conclusions:} decrease in patients with diabetic nephropathy.
Irisin was significantly decreased in type 2 diabetic patients compared to control $(34.46 \pm 15.28 \mathrm{ng} / \mathrm{ml}$ vs. $152.600 \pm 39.581 \mathrm{ng} / \mathrm{ml}, \mathrm{p}<0.001)$. Patients with $\mathrm{DN}$ had lower irisin than diabetics without complications $(20.967 \pm 4.476 \mathrm{ng} / \mathrm{ml}$ vs. $47.967 \pm 8.853 \mathrm{ng} / \mathrm{ml}, \mathrm{P}<0.01)$. There was a significant negative correlation between irisin and systolic blood pressure $(r=-0.493)$, diastolic blood pressure $(r=-$ $0.625)$, serum creatinine $(r=-0.729)$, duration of diabetes $(r=-0.942)$, albumin/creatinine ratio( $r=-0.696)$, $\mathrm{BMI}(\mathrm{r}=-0.396)$ and $\mathrm{HbA} 1 \mathrm{c}(\mathrm{r}=-0.305)$ in all diabetic patients. $(p<0.05)$. Multivariant regression analysis showed that duration of diabetes is the only independent determinant for irisin level. 